\title{
Falconiformes Assemblages in a Fragmented Landscape of the Atlantic Forest in Southern Brazil
}

\author{
Alan Loures-Ribeiro ${ }^{1,3^{*}}$ and Luiz dos Anjos ${ }^{1,2}$ \\ ${ }^{1}$ Programa de Pós-Graduação em Ecologia de Ambientes Aquáticos Continentais; Bloco G-90; Universidade \\ Estadual de Maringá; Avenida Colombo 5790; 87020-900; Maringá - PR - Brasil. ${ }^{2}$ Departamento de Biologia \\ Animal e Vegetal; Universidade Estadual de Londrina; C. P. 6001; 86051-970; Londrina - PR - Brasil. ${ }^{3}$ Centro \\ Universitário do Leste de Minas Gerais; Laboratório de Vertebrados; Núcleo de Estudos Biológicos; Av. Tancredo \\ Neves, 3500; Bairro Universitário; 35170-056; brazilraptors@yahoo.com.br; Coronel Fabriciano - MG - Brasil
}

\begin{abstract}
An ecological analysis focused on distribution of Falconiformes, comprising abundance and morphology data, is provided. Samples were collected in a fragmented landscape within the Atlantic Rainforest, southern Brazil, between August and November 2001. Four main types of habitats were pinpointed among the 30 different sampling sites, while eight external morphological traits were employed. Twenty-one Falconiformes species were detected and jackknife estimates for regional richness reached $24.8 \pm 2.56$ species $(p<0.05)$. There were no differences between average number of diurnal birds of prey species in the different habitats under analysis $(H$-test, $p>0.05)$. Mantel's test for relative abundance and species morphology reveals weak association rates, corroborating the lack of association between matrixes $(r=0.059, p>0.05)$. Difficulties in the analyses of distribution and species morphology data may have been caused by their generalist character and may be due to the high rate of environment degradation revealed by the regional landscape's mosaic aspect.
\end{abstract}

Key words: Birds, distribution, Falconiformes, habitat analysis, richness, southern Brazil

\section{INTRODUCTION}

Inserted within the neotropical region, the South America has approximately 3,100 bird species, or $32 \%$ of world total known (Bildstein et al., 1998; Bierregaard, 1998). In spite of the great number of diurnal birds of prey on the continent (84 species), the biology of just a few is sufficiently known, so that a precise diagnosis of their current status is almost impossible (Thiollay, 1985c; Bierregaard, 1998). Loss of habitats, especially in tropical forests to which at least $45 \%$ of Falconiformes are linked, may be a worsening factor for the preservation of diurnal birds of prey (Bildstein et al., 1998). Deforestation rate in the tropical regions of the Americas has been close to 74 million hectares (48\% of world total) between 1981 and 1990 (Whitmore, 1997).

Relevant data on Falconiformes assemblages of the neotropical region are available from French Guiana (Thiollay, 1985a; 1989; 1991; 1997; 1999), Peru (Robinson, 1994) and Guatemala (Gerhardt et al., 1993; Thorstrom, 1997; Seavy et al., 1997; Panasci and Whitacre, 2000). Albuquerque (1995) has reported the occurrence of more sensitive species in the Brazilian Atlantic Rainforest and analyzed some aspects of their biology and habitat.

${ }^{*}$ Author for correspondence 
The distribution of diurnal birds of prey throughout different environments is probably linked to adaptations in morphology, behavior and ecology, mainly in forest-inhabiting species. As a rule, more sensitive species may reveal the broadness of a smaller niche, which causes them to be more susceptible to local changes such as the disturbance or the loss of some factors proper to their survival (Brown, 1984; Newton, 1991). These are only speculations since precise knowledge of the species' biological characteristics are insufficient (Thiollay, 1985b).

Current research will comprise an analysis of the ecology of assemblages of diurnal birds of prey in an area in southern Brazil so that the spatial distribution of Falconiformes throughout the main habitats may be investigated. The relationship between relative abundance and species morphology will be also investigated for possible explanations on local mechanisms involved in the organization of assemblages.

\section{MATERIALS AND METHODS}

\section{Study sites}

The area lies in northwestern region of the state of Paraná and the southeastern region of the state of Mato Grosso do Sul, Brazil, bordered on the east by the municipality of Maringá, Paraná State, Brazil $\left(23^{\circ} 24^{\prime} \mathrm{S} / 51^{\circ} 56^{\prime} \mathrm{W}\right)$, on the north by Paranapanema river $\left(22^{\circ} 40^{\prime} \mathrm{S} / 53^{\circ} 00^{\prime} \mathrm{W}\right)$, on the south by Ivaí river $\left(23^{\circ} 30^{\prime} \mathrm{S} / 53^{\circ} 45^{\prime} \mathrm{W}\right)$ and on the west by the upper Paraná river floodplain, Mato Grosso do Sul, Brazil, (22 $54^{\circ}$ 'S $\left./ 53^{\circ} 38^{\prime} \mathrm{W}\right)$, lying at 100 - $450 \mathrm{~m}$ above sea level (Fig. 1).

The upper Paraná river floodplain, one of the best sampled areas (Fig. 1B), is the tenth largest river in water discharge in the world and the second largest basin in South America. In fact, it is the main river within the "la Plata basin" (Stevaux, 1994). The floodplain is the last non-dammed stretch between the Porto Primavera Hydroelectric Dam to the north and the Itaipu Reservoir to the south and it is a relevant area of environmental preservation. The regional water cycle influences the floodplain in which 3-meter oscillations in hydrometric levels during the high water period cause several flooding pulses (Thomaz et al., 1997).
The specific floodplain area includes riparian vegetation such as seasonal, submountain, alluvial semi-deciduous forests and grasslands with large areas of wetlands and pasture for cattle-raising (Romagnolo and Souza, 2000). The area may be considered an ecotone zone between the Atlantic Rainforest and the savannas of southeastern Mato Grosso do Sul. The latter is in a better state than that found in the northwestern area of Paraná (Campos et al., 2000).

The northwestern area of Paraná is entirely occupied by agricultural and cattle-raising areas. While in some places the primordial vegetation reaches a mere $1 \%$ (Campos et al., 2000), there is no more than $3 \%$ of Atlantic forest remnants in our study area at different succession stages (Fig. 1A). Only rarely over-300-ha fragments are extant (Straube et al., 1996; Fundação SOS Mata Atlântica and INPE, 1998).

Forest fragments consist of seasonal semideciduous forests with some special types of vegetation formation, savanna-like stretches (spaced shrub vegetation) and grasslands near the wetland zones of some rivers (Straube et al., 1996). Parts of the region lie on the Cretaceousformed Caiuá formation of the Paraná river valley (Stevaux, 1994).

Regional climate is Cfa (tropical-subtropical, according to Köeppen), with hot summers (average $27^{\circ} \mathrm{C}$ ) and average annual rainfall 1,500 $\mathrm{mm}$. Rainfall, always higher than $30 \mathrm{~mm}$, occurs all the year round, with greater and lesser volumes respectively between September/December and June/August (Centrais Elétricas do Sul do Brasil, 1986).

\section{Species composition}

The point counts technique (Fuller and Mosher, 1987), adapted for most diurnal birds of prey in tropical regions (Thiollay, 1996; 1999), from August to November 2001 (breeding period), registered the minimum number of individuals of each species in $1 \mathrm{~km}^{2}$ sample areas, during four hours, in the same day, by standard procedures. Thirty $1 \mathrm{~km}^{2}$ areas were sampled. During the same period flooded areas were visited or circumnavigated by boat or investigated along dirt roads by car so that any possible diurnal bird of prey still not detected by point counts technique could be registered. In all some $1200 \mathrm{~km}$ of road were covered. 


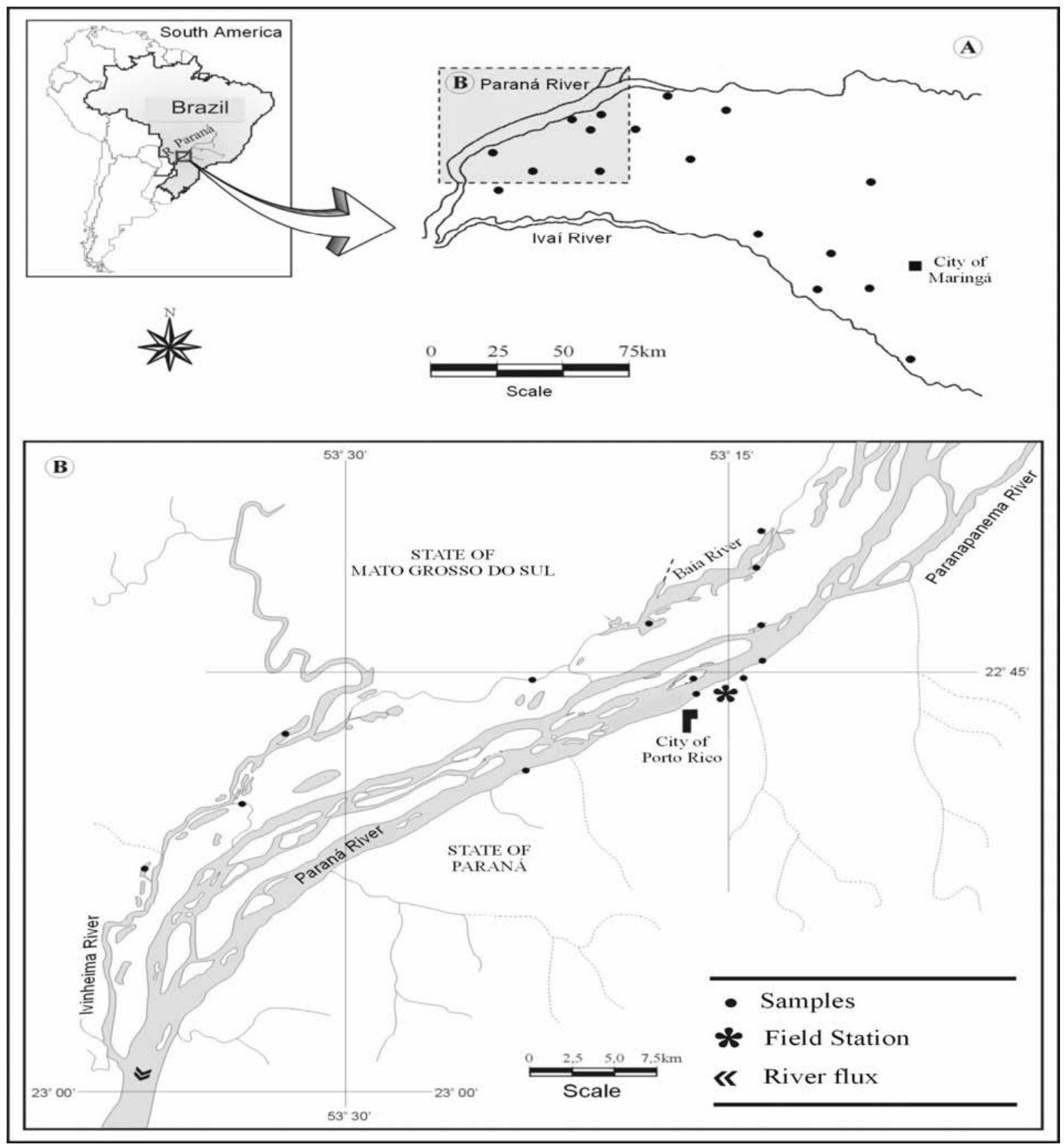

Figure 1 - Study area (A. Northwestern region of the Paraná State; B. Upper Paraná river floodplain).

Species were identified by $8 \times 35$ and $7 \times 50$ binoculars and by vocalizations. Only grounded birds and birds foraging for food or executing displays within the sampling units have been taken into account. Immature birds, birds that were merely crossing the space or flying very high above normal foraging height were discarded. Reports were obtained by vocalizations with two specimens in each unit at the most, and thus overestimation was avoided.
When possible, squares were sampled from one or two vantage points of the most representative environment of each sampling unit. Sample limits were established by GPS Garmin and odometer. Squares were chosen at random and placed in areas close to roads and pathways for easy access. Samples were taken in good weather conditions (breeze to moderate wind and 25\% cloud-covered sky). Areas were visited in early morning, between 6:30 and 10:30 h (approximately 30 to $40 \mathrm{~min}$ 
after sunrise). During the first couple of hours we visited pathways in the midst of the forest where vegetation was predominant. The other couple of hours were spent in inspecting treetops from one or two vantage points. At sunset search was completed in the forest environments so that species not detected in the morning could be listed. Species registered out of the squares were not included in ecology and morphology analyses. They were merely jotted down as present in the region under study. Since analysis methodology is a point counts technique, results cannot be taken as a complete census of the sites, but mere indexes of relative abundance. No comparison between species indexes may be undertaken since great differences in detection occur.

Some species are liable to be overestimated (catartids) and others underestimated (species from the inner forest) despite criteria in species registration. This is due to their great mobility and rare habits. However, errors have been lessened with regard to species living in the forest interior, either because they fly during a short period of time, especially in the morning, or because of vocalization (Thiollay, 1996).

Species are characterized according to their habitat data found in Appendix 1 (Thiollay, 1985a). Species follow systematic and nomenclature respectively suggested by Meyer de Schauensee (1982) and Sick (1997).

Main habitats in the region were classified into four types: (1) grasslands $(n=13)$ were dominant in the areas under analysis, especially in the northwestern region of Paraná. They are chiefly formed by deforested areas, abandoned fields with low vegetation growths, pastureland for cattleraising with a high degree of human activity; (2) wetlands $(n=4)$ are found exclusively in the Paraná river floodplain; they are floodable or partially flooded areas, directly or indirectly linked to rivers, and highly susceptible to natural disturbances, especially from flood pulses; (3) riparian corridors $(n=6)$ of the Baía and Ivinheima rivers (state of Mato Grosso do Sul) and Paraná and Ivaí rivers (Paraná State); shrub-like vegetation in marginal areas of rivers, lakes, swamps and artificial lakes; (4) forest remnants (n $=7$ ) at different succession stages of the northeastern region of the Paraná State; continuous native vegetation mostly with tree. Since some sampling units formed environment mosaics, a habitat was predominant when forest occurrence reached $60 \%$ or over of total square.

\section{Additional comments and statistical analysis}

418 skins of 19 species from three museums (National Museum of Rio de Janeiro; Zoology Museum of São Paulo University, São Paulo; Museum of Natural History Capão do Imbuia, Paraná) were measured. External morphological variables were obtained by length $(\mathrm{mm})$ of: (1) wings, measured from the region prior to curvature (small depression) as far as its extremity in specimens with closed wings; (2) primary and (3) secondary feathers, taking into consideration the longest; (4) tail, measured from the insertion point at the rump bone to the extremity of the longest tail feathers; (5) tarsus, measured from the posterior-superior extremity to the anthero-inferior tarsus-metatarsus; (6) middle finger, measured from its start to the claw base; (7) culmen, measured between the anterior margin top of crown to the tip of the bill; (8) claw, measured by toe grasp. Measurements were done by compass according to Leisler and Winkler (1991) and Sick (1997).

$H$-test (Kruskal-Wallis test) was applied for possible differences between mean number of Falconiformes (mean \pm SD) in each type of habitat $(p<0.05)$. Species' frequency and relative abundance were calculated by the percentage of squares in which each species occurred and by the mean number of specimens per species with regard to all sampling unities $\left(\mathrm{n}=30\right.$ squares of $\left.1 \mathrm{~km}^{2}\right)$. Since relative abundance rates proceed from the minimum number of individuals in each sampling unit (simultaneously reported for two or more specimens), species numbers are conservative.

Detrended correspondence analysis (DCA) sought possible environmental gradient that might be explained by the relative abundance of species (Jongman et al., 1995). Due to the number of zeroes in sampling units (rare species), values were square rooted (Fowler et al., 1998). Scores between different habitats from species' relative abundance were compared by $H$-test $(\mathrm{p}<0.05)$. Dunn's multiple comparison test $(\mathrm{p}<0.05)$ verified the possible differences between habitat scores.

Congruency between ecology (species' relative abundance) and morphology data was verified by Mantel's test for association between matrixes, and Monte Carlo's randomization test with 9,999 randomizations $(\mathrm{p}<0.05)$ for their significance (Diniz-Filho and Bini, 1996). Normalization was done by subtracting matrix mean of each factor and dividing it by standard deviant of factors from each matrix. Procedure is highly useful when 
different variables are used to compare results (Fortin and Gurevitch, 1993). Euclidean distance was used in both matrixes (Valentin, 1995).

Richness of Falconiformes species was estimated by Jackknife method (squared sample units), according to formula $\mathrm{S}=\mathrm{s}+(\mathrm{n}-1 / \mathrm{n}) \mathrm{K}$, where $S$ is the Jackknife estimate of species richness; $s$ is the total number of species in $n$ squares (samples) and $K$ is the number of species in a single square (Krebs, 1999). Richness rate was expressed by mean \pm SD $(\mathrm{p}<0.05)$.

Data were analyzed by STATISTICA 6.0 (StatSoft, 1997) and PC-ORD 4.01. The latter was used in Mantel's test (McCune and Mefford,
1999). Species richness was estimated by RICHNESS 5.1 (Krebs, 1998).

\section{RESULTS}

Nineteen species of diurnal birds of prey were reported in the 30 sampled areas by point counts technique (Table 1). Sites overrun by boat or car increased the number of species by two (Pandion haliaetus and Falco rufigularis), not detected in these areas. Jackknife estimates for richness of region reached $24.8 \pm 2.56$ species $(\mathrm{p}<0.05)$.

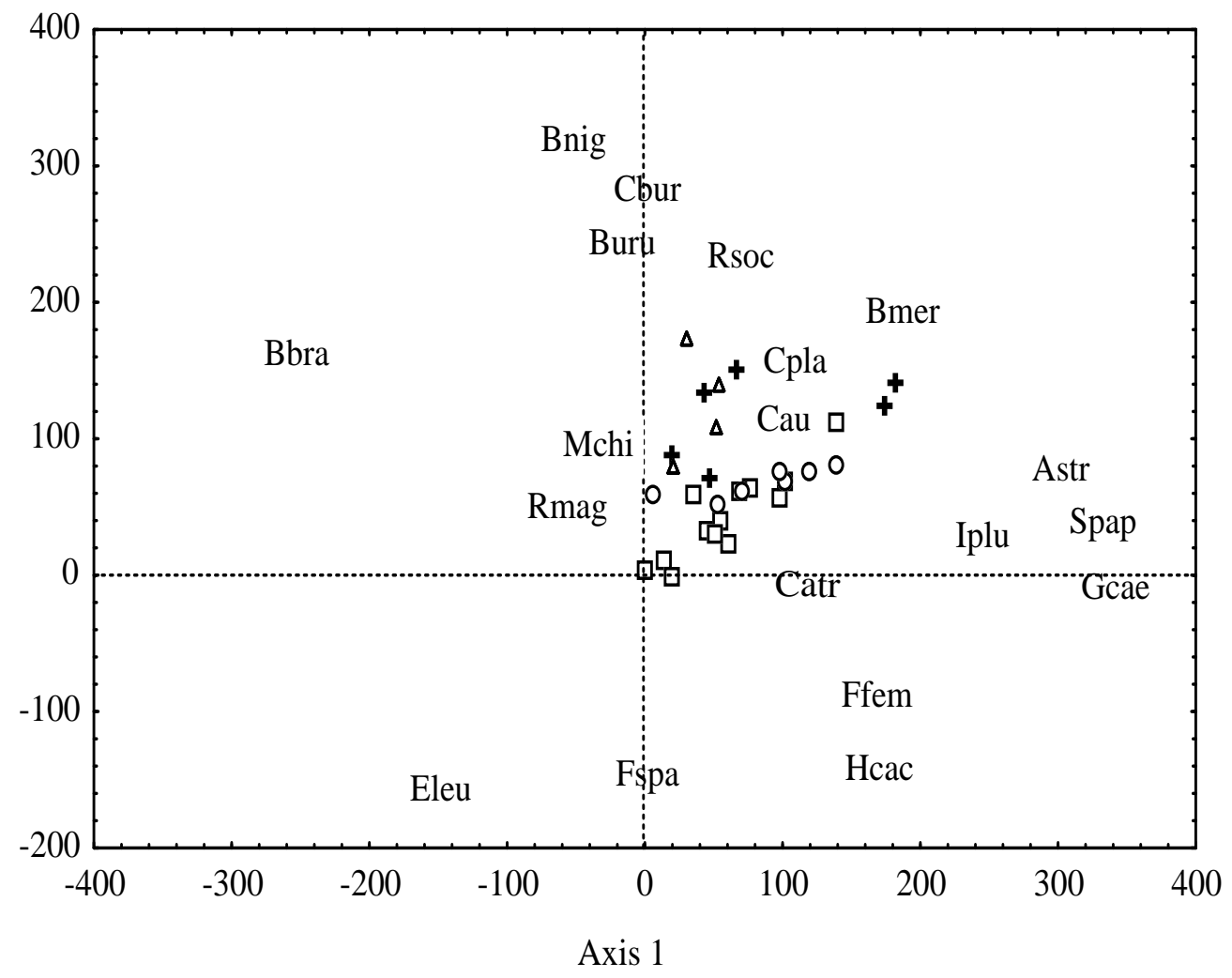

Figure 2 - DCA ordination diagram from abundance data of the species (Eigenvalue A1 $=0.338$ ). Species: Spap = Sarcoramphus papa $;$ Catr = Coragyps atratus $;$ Cau = Cathartes aura; Cbur = Cathartes burrovianus; Eleu = Elanus leucurus; Iplu = Ictinia plumbea $;$ Rsoc = Rostrhamus sociabilis; Astr = Accipiter striatus; Rmag = Rupornis magnirostris; Bbra = Buteo brachyurus; Bnig = Busarellus nigricollis; Bmer = Buteogallus meridionalis; Buru = Buteogallus urubitinga; Gcae = Geranospiza caerulescens; Hcac = Herpetotheres cachinnans; Mchi = Milvago chimachima $;$ Cpla = Caracara plancus $;$ Ffem = Falco femoralis ; Fspa $=$ Falco sparverius . Cross $=$ Forest, circle $=$ riparian corridors, triangle $=$ wetland, square $=$ grassland. 


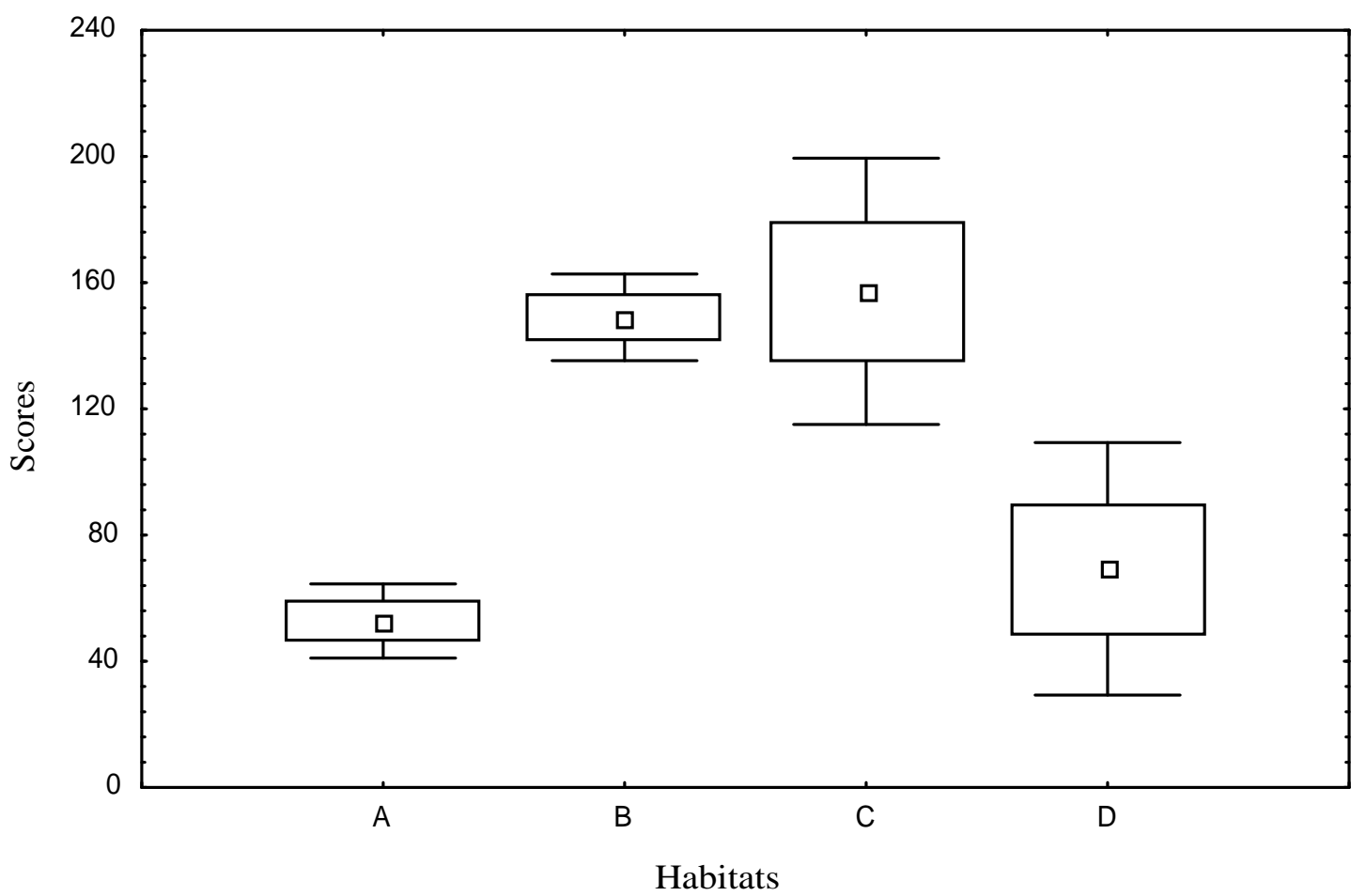

Figure 3 - Mean scores of the one axis of DCA for distinct habitats. A - Grassland; B - Riparian corridors; C - Wetland; D - Forest remnants.

Species' mean numbers among the different sampled environments (forest $=6.628 \pm 2.225$; riparian corridor $5.0 \pm 2.0$; wetlands $=5.0 \pm 1.826$ and grassland $=4.615 \pm 1.044)$ did not differ significantly ( $p>0.05)$. Approximately $52.64 \%$ of species (10/19 species) occurred in two or more types of habitats; the remaining $47.36 \%$ were reported in a predominant type of habitat. When sensitivity and habitat occupation rates (Appendix 1) are taken into account, tolerant and open area species (generalists, amounting to $61.9 \%$ ) were predominant when compared to relatively tolerant and sensitive (23.8\%). Other species (14.3\%) have always been related to water environments. Coragyps atratus, Cathartes aura, Rupornis magnirostris, Caracara plancus and Falco sparverius are the most common among toleran and open area species. Among the relatively tolerant and sensitive Accipiter striatus, Geranospiza caerulescens, Falco rufigularis, Ictinia plumbea and Sarcoramphus papa may be mentioned. The latter species is the most sensitive and has been reported only in the Ecological Station of Caiuá. Pandion haliaetus, Rostrhamus sociabilis and Busarellus nigricollis are water environment associated species.

DCA indicated that species distribution partially explained environmental gradient (eigenvalue = 0.338; Fig. 2). Tolerant and open area species, $C$. atratus, $C$. plancus and $R$. magnirostris, tended to have their distribution close to the axis center. Other species characterized by more specific habitats, $R$. sociabilis and B. nigricollis, normally associated with swampy environments, and $S$. papa and G. caerulescens, associated with forest environments, remained close to axis extremities.

When DCA values of axis 1 were plotted according to mean habitat score, a trend in the continuum pattern of the species was reported (Fig. 3). Riparian corridor and wetland scores were closer when compared with forest and grasslands values. Significant differences were registered between distinct habitats $(\mathrm{p}<0.05)$. Grassland and wetlands scores $(\mathrm{p}<0.05)$ and forest and wetland scores were different $(\mathrm{p}<0.05)$, although eigenvalue (0.338) was not a significant environmental gradient. 
Table 1 - Habitats, frequency and relative abundance of Falconiformes in the study area. Contacts in each distinct habitat are in percentage; dominant habitat (> 60\% of contact for each species) in bold.

\begin{tabular}{|c|c|c|c|c|c|c|c|}
\hline \multirow[t]{2}{*}{ Taxa } & \multicolumn{4}{|c|}{$\begin{array}{l}\text { Habitat }{ }^{\mathrm{a}} \\
(\%)\end{array}$} & \multirow[t]{2}{*}{$\mathrm{C}^{\mathrm{b}}$} & \multirow[t]{2}{*}{$\underset{\mathrm{c}}{\text { Frequency }}(\%)$} & \multirow[t]{2}{*}{ Abundance $^{\mathrm{d}}$} \\
\hline & $\mathrm{F}$ & $\mathrm{R}$ & $\mathrm{W}$ & $\mathrm{G}$ & & & \\
\hline \multicolumn{8}{|l|}{ Cathartidae } \\
\hline Sarcoramphus papa & 100 & - & - & - & S & 3.33 & 0.1 \\
\hline Coragyps atratus & 21.86 & 19.83 & 15.8 & 42.51 & $\mathrm{O}$ & 96.6 & 8.23 \\
\hline Cathartes aura & 28.57 & 50.64 & 5.21 & 15.58 & $\mathrm{O}$ & 66.6 & 2.56 \\
\hline $\begin{array}{l}\text { Cathartes burrovianus } \\
\text { Pandionidae }\end{array}$ & - & 44.5 & 55.5 & - & $\mathrm{O}$ & 23.3 & 0.6 \\
\hline $\begin{array}{l}\text { Pandion haliaetus } \\
\text { Accipitridae }\end{array}$ & - & - & - & - & $\mathrm{We}$ & - & - \\
\hline Elanus leucurus & - & - & 16.7 & 83.3 & $\mathrm{O}$ & 16.6 & 0.2 \\
\hline Ictinia plumbea & 100 & - & - & - & Rt & 20.0 & 0.43 \\
\hline Rostrhamus sociabilis & - & 35.3 & 64.7 & - & $\mathrm{We}$ & 20.0 & 0.56 \\
\hline Accipiter striatus & - & 100 & - & - & Rt & 3.33 & 0.03 \\
\hline Rupornis magnirostris & 29.26 & 29.26 & 2.46 & 39.02 & $\mathrm{~T}$ & 73.3 & 1.36 \\
\hline Buteo brachyurus & 100 & - & - & - & $\mathrm{T}$ & 3.33 & 0.03 \\
\hline Busarellus nigricollis & - & 100 & - & - & $\mathrm{We}$ & 6.66 & 0.1 \\
\hline Buteogallus meridionalis & - & 100 & - & - & $\mathrm{O}$ & 3.33 & 0.03 \\
\hline Buteogallus urubitinga & - & 100 & - & - & $\mathrm{O}$ & 3.33 & 0.03 \\
\hline $\begin{array}{l}\text { Geranospiza caerulescens } \\
\text { Falconidae }\end{array}$ & 100 & - & - & - & Rt & 3.33 & 0.03 \\
\hline Herpetotheres cachinnans & 100 & - & - & - & $\mathrm{T}$ & 6.66 & 0.06 \\
\hline Milvago chimachima & 47.05 & 17.66 & - & 35.29 & $\mathrm{O}$ & 36.6 & 0.56 \\
\hline Caracara plancus & 50 & 14.7 & 11.78 & 23.52 & $\mathrm{O}$ & 66.6 & 1.13 \\
\hline Falco rufigularis ${ }^{\mathrm{e}}$ & - & - & - & - & Rt & - & - \\
\hline Falco femoralis & 42.86 & - & - & 57.14 & $\mathrm{O}$ & 16.6 & 0.23 \\
\hline Falco sparverius & - & - & 4.35 & 95.65 & $\mathrm{O}$ & 46.6 & 0.76 \\
\hline
\end{tabular}

The Fig. 4 shows average values of the eight external morphological characteristics. With the exception of catartids with few skin specimens in museums, species' sexual ratio ranged between 0.45 and 0.55 . Only adult specimens have been taken into consideration.
Mantel's test for matrix association showed a positive relationship between relative abundance data and species morphology, even though a weak association rate has been suggested $(r=0.059)$.

Based on randomizations, the null hypothesis of no association between matrixes was accepted $(\mathrm{p}>0.05)$. 


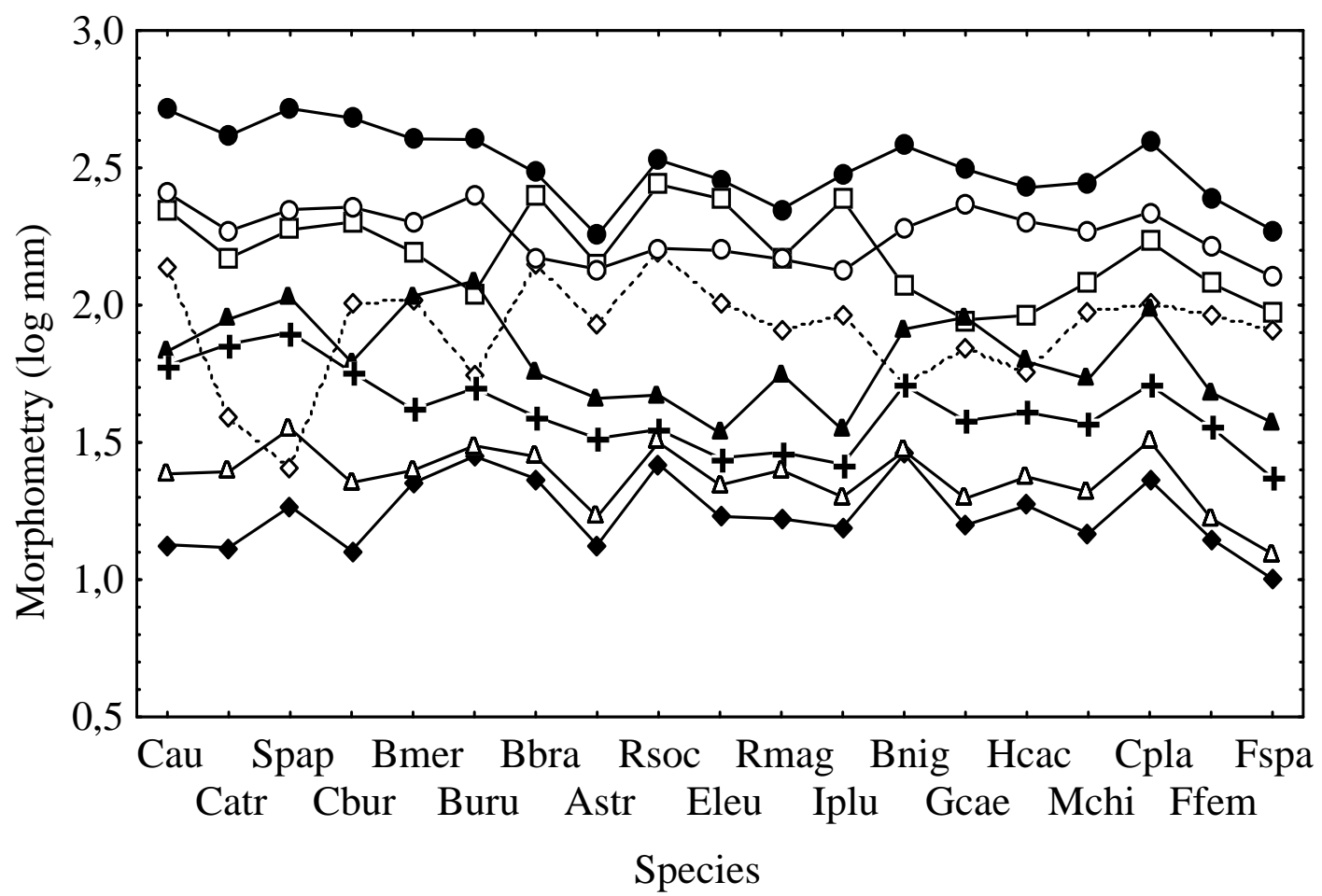

Figure 4 - Mean values of the eight external morphological aspects measured from 19 species of Falconiformes (log mm). Lenghts: • Wing; ○ Tail; $\square$ Primary; $\diamond$ Secondary; $\boldsymbol{\Delta}$ Tarsus; + Toe; $\Delta$ Bill; $\triangleleft$ Claw.

\section{DISCUSSION}

The degree of environmental disturbance can influence the community's composition through the disappearance of a lot of species, causing a significant loss of the regional biodiversity (Olrog, 1985; Thiollay, 1999; Lovejoy et al., 1986; Por, 1992). These disturbances mainly cause changes in extant interspecific relationships (Ricklefs, 1989; Ferrari, 1990; Egler, 1991; Krakauer and Krakauer, 1999; Zhang and Wang, 2000) and may even to take other future local extinctions (Brown, 1995; Chapin III et al., 2000; McCann, 2000).

Almost all the sites under analysis underwent various degrees of human disturbance. In spite of some better-preserved areas, stretches which have been recently consumed by forest fire may be perceived. Further, one may easily note that indiscriminate hunting is one of the regional customs of ranchers and inhabitants. Therefore, the commonest disturbances in forest areas consist of selective cutting of timber, hunting and intense agricultural activities in the neighborhood, including the use of heavy machinery in the interior of forest remnants.

Thiollay (1985a; 1997) calculated between $40 \%$ and $56 \%$ the loss of species richness in regions of the Amazon affected by different rates of degradation. Fletcher et al. (1999) perceived disturbance effects in diurnal birds of prey in human-affected environments. Severe decrease in species richness may also be caused by the absence of preservation areas, since most birds of prey depend on vast regions for their survival (Thiollay, 1989; 1994; Robinson, 1994; Fuller, 1996). The inconspicuous habits and low densities of many Falconiformes species make their localization extremely difficult (Thiollay, 1985a; 1985b) and their numbers may have been underestimated in spite of efforts taken to detect them.

The above factors may have contributed towards the absence of significant differences among Falconiformes along the region's environments. Furthermore, some diurnal birds of prey $(A$. striatus, B. meridionalis and B. urubitinga) have low frequency. Intense human disturbance may 
decrease populations in a considerable way, chiefly because of loss of forest habitats (Gilpin and Soulé, 1986). This leads us to the conclusion that some diurnal birds of prey can be threatened since their population size is unknown. Due to the fact that no historical data on the composition and abundance of these birds in the northwestern region of the Paraná State are available, the above considerations are merely speculative and should be examined with great care.

Preston (1990) and Thiollay (1996) insist on the difficulty in determining the habitat of diurnal birds of prey, especially in sites with mosaic vegetation. Pinpointing preferences in habitat for Falconiformes may undoubtedly be a difficult task. Analyzing semi-arid environments around the Mediterranean Sea, Sanchez-Zapata and Calvo (1999) mentioned problems with regard to the type of habitat used by diurnal raptors and emphasized that links between species of diurnal birds of prey and their habitat have varied according to the adopted scale.

Distribution of Falconiformes species throughout the different environments of the region showed a relative trend of affinities throughout a number of habitats, chiefly between riparian corridor and wetlands, followed by forest and grasslands, although there were no significant differences between grassland and forest scores vis-à-vis riparian corridors. However, the number given by axis 1 of DCA should not be taken as very relevant, since there were differences in the variances of habitat scores. Consequently, the heterogeneity of sampled units (abiotic data were not measured) may be one of the factors that affected the search for such possible gradients.

Dobrowolski (1994) reported that there may exist a multi-environment zone along the floodplain of a big river, forming an extensive ecotone. This may be one of the factors that would explain the close DCA scores for riparian corridor and wetlands. Similarly, it would explain the possible variability of part of the set of the sampling units with regard to the abiotic and biotic aspects. Further, the difference between grassland and forest scores and the wetland scores may be due to species $(C$. burrovianus and $R$. sociabilis, for instance) with relative affinity for swampy or floodable areas.

One of the presuppositions linked to gradient analyses and to the continuum pattern refers to biological differences or similarities among species. Availability of resources for a community is a multidimensional continuum where only a slight portion is used by a certain species, and thus defining its niche range (Brown, 1984; 1995). Owing to the ecological characteristics of diurnal birds of prey (most of them are generalists) and to the situation of the researched area (with a high level of environmental degradation), one may say that the investigation on gradients by such species has been greatly impaired. Stotz et al. (1996) corroborate this result when they classify $C$. aura, $C$. atratus, E. leucurus and B. magnirostris as typical species of disturbed areas.

Matrix incongruence between relative abundance data and morphological variables suggests evidence reported in ecomorphological studies. Price (1991) insists on more information in the case where multiple factors interact in the choice of habitat by a species. In their study on the relationship between habitat, morphology and behavior of diurnal birds of prey in the Philippines, Gamauf et al. (1998) found sufficient clues to assert the autonomy of aspects within the same niche. This fact has also been confirmed by Price (1991).

\section{Conservation status of diurnal birds of prey}

Fifty-two species of diurnal birds of prey, distributed throughout different environments, have been listed for the Paraná State (Scherer-Neto and Straube, 1995).

Based on data collected by Pinto (1978), Straube et al. (1996) and from museum specimens, some species, currently considered threatened in the northwestern region of the state of Paraná, were more widely distributed some years ago. Among the catartids $S$. papa has been registered in the Ivaí river valley, Serra Dourada, Piquiri river, Vila Guarani, Guaíra; estuary of the Ivaí river and Diamante do Norte city. Probably the species could be found in other areas of the region. At present it is restricted to more preserved sites (Houston, 1985). Leucopternis polionota (Ilha Grande - Paraná river), Spizastur melanoleucus (Morro do Diabo State Park, border of state), Spizaetus ornatus and Accipiter poliogaster (Paraná river), Daptrius americanus (Ivaí river valley, Paranapanema and Paraná rivers), Harpyhaliaetus coronatus (Upper Paraná river, M. R. Gimenes pers. comm.), have also been reported. It is highly probable that these species might have occurred in the region under analysis in spite of the fact that they have been reported at border sites. 
Research in the north of Paraná along Atlantic forest remnants shows species that have not been registered in our study (Anjos and Graf, 1993; Anjos et al., 1997; Krügel and Anjos, 2000; Anjos, 2001). It is probable that some of these species (Harpagus diodon, Leptodon cayanensis and Micrastur ruficollis) may be found in forest remnants of the northwestern region of the state of Paraná. However, other sites have shown a composition of diurnal birds of prey which is similar to that described here (Anjos and Seger, 1988; Anjos and Boçon, 1999). Detection of some species in above-mentioned researches may be mainly related to differences in the method, since in this group a low rate of detectability may occur. Nevertheless, it should be insisted that diurnal birds of prey have been registered with low frequency rates.

Although common in many Brazilian regions, $C$. burrovianus is a less known species (Stotz et al., 1996). Data suggest that the species is more frequent in areas close to the floodplain. Stotz et al. (1996) state that the Catartidae may be taken as a clue for seasonally flooded areas in the Amazon region. However, it may also be possible that in its distribution the species shows also greater affinities with floodable areas in other regions, even though current data are not part of a regional census.

\section{Preliminary strategies for the conservation of the ecosystem}

The conservation of diurnal birds of prey will greatly benefit from an immediate interruption of habitat destruction, especially, forest remnants.

According to Thiollay $(1989 ; 1994)$ a continuous area of more than a million hectares would maintain a viable assemblage of diurnal birds of prey during a long period of time. At present few continuous preserved areas reach the minimum area necessary for the maintenance of these species. In the case of the Atlantic Rainforest only the Brazilian states of Minas Gerais, Paraná, São Paulo and Santa Catarina have forest remnants with area above of one million hectares. Although the Atlantic Rainforest is one of Paraná's chief vegetation types, it is practically restricted to the coastal strip and to the Iguaçu Falls National Park (Fundação SOS Mata Atlântica and INPE, 1998). Thiollay (1989) doubts whether small forest reserves are capable of preserving species of Falconiformes, even though biological corridors have lessened their isolation (Micrastur sp, for instance).

Interruption of environment impairing activities, such as paths and dirt roads in the forest interior (Goosem, 1997), selective tree felling (Whitmore, 1997), cattle and domestic animals in forest remnants (Jordan, 1986) and hunting (Thiollay, 1999), will greatly increase the conservation of diurnal raptors species. The isolation of these forest remnants with hedges and a drastic decrease of agricultural activities in the neighborhood will be a great asset.

Stotz et al. (1996) emphasize the importance of preserving distinct habitats that occur side by side (ecotones). In the upper river Paraná floodplain, a transitory area between the Atlantic Rainforest of the state of Paraná and the Mato Grosso do Sul savanna (Campos et al., 2000), predators would use the dense vegetation to hunt their prey in these ecotones. However, great parts of the region have been extensively degraded and completely depleted the forest remnants of the Atlantic Rainforest on the left bank of the Paraná river. The upper Paraná river region is currently recommended to be an environment protected area and a state park (right bank of the river Paraná).

In the case of species that directly depend on water resources for their food, mainly $P$. haliaetus (fish), $R$. sociabilis (snails) and B. nigricollis (fish and amphibians), preservation of river and riparian corridors is a must (Magalhães, 1990a; 1990b; Sick, 1997). The main threat to the species in the upper river Paraná floodplain, the only undammed stretch of such an important river, consists of the hydroelectric power stations built along its full extension.

\section{APPENDIX 1}

Classification of species according to Thiollay (1985a) related to different succession stages of vegetation and environment integration.

A - Sensitive species (S), with more demanding habitat requirements; generally associated to relatively undisturbed environments. Sarcoramphus papa.

B - Relatively tolerant species (RT), more tolerant to changes in primordial environment; generally abundant in intermediary succession stages. Ictinia plumbea; Accipiter striatus; Geranospiza caerulescens; Falco rufigularis. 
C - Tolerant species $(\mathrm{T})$, absent in primary forests and associated to stretches of secondary forests and to sites filled with trees. Rupornis magnirostris, Buteo brachyurus; Herpetotheres cachinnans.

D - Open area species (O; generalist), associated to open area, found in forest clearing with few trees; capable of expanding their distribution to remnant forests. Coragyps atratus; Cathartes aura; Cathartes burrovianus; Elanus leucurus; Buteogallus meridionalis; Buteogallus urubitinga; Milvago chimachima; Caracara plancus; Falco femoralis and *Falco sparverius.

*E - Water species (Aq), associated with swampy or floodable areas; in these areas the species have their chief requirements for survival. Pandion haliaetus; Rostrhamus sociabilis and Busarellus nigricollis.

*Classification of these species does not follow Thiollay (1985a) and is based on general aspects of their respective biology (Sick, 1997).

\section{ACKNOWLEDGEMENTS}

The authors would like to thank the CAPES for scholarship grant to Alan Loures-Ribeiro. Luis dos Anjos has received grants from APQ/CNPq. Field activities have been supported by $\mathrm{PELD} / \mathrm{CNPq}$ and PEA/NUPELIA of the State University of Maringá. We would also like to thank L. F. da Silveira (Zoology Museum of USP) for permission to use the ornithology collection; D. Urban (UFPR, Curitiba) for data on species morphology; A. M. dos Santos (UEM/PEA) for helping in statistic data; J. L. B. Albuquerque (UNISUL, Florianópolis) and E. Goulart (UEM/PEA/NUPELIA) for suggestions on the first version of the manuscript; proprietors and curators of areas studied.

\section{RESUMO}

Uma análise ecológica enfocando a distribuição das espécies de Falconiformes foi realizada, empregando dados de abundância e morfologia. As amostragens foram feitas em uma região de paisagem fragmentada sob o domínio da Floresta Atlântica, sul do Brasil, entre agosto e novembro de 2001, durante o período reprodutivo das espécies. A partir de 30 diferentes locais de amostragem, quatro principais tipos de hábitats foram encontrados (fragmentos de floresta, mata ciliar, várzea e campo/pastagem). Oito caracteres morfológicos externos foram utilizados nas análises. Foram detectadas 21 espécies de Falconiformes, sendo a estimativa Jackknife para a riqueza regional de $24.8 \pm 2.56$ espécies ( $\mathrm{P}<$ 0.05). Não existiram diferenças para o número médio de espécies de aves de rapina diurnas entre os hábitats investigados (K-test, $\mathrm{P}>0.05$ ). $\mathrm{O}$ teste de Mantel para os dados de abundância relativa e morfologia das espécies indicou um fraco grau de associação, concordando com a hipótese de nenhuma associação entre as matrizes $(\mathrm{r}=0.059, \mathrm{P}$ $>0.05$ ). As dificuldades encontradas nas análises dos dados de distribuição e de morfologia das espécies podem ter sido geradas pelo caráter generalista da maioria delas e, ainda, associadas ao intenso grau de degradação ambiental, responsável pelos mosaicos da paisagem regional.

\section{REFERENCES}

Albuquerque, J. L. B. (1995), Observations of rare raptors in southern Atlantic rainforest of Brazil. $J$. Field Ornitol., 66, 363-369.

Anjos, L. (2001), Bird communities in five Atlantic Forest fragments in southern Brazil. Ornitol. Neotrop., 12, 11-27.

Anjos, L. and Seger, C. D. (1988), Análise da distribuição das aves em um trecho do rio Paraná, divisa entre os estados do Paraná e Mato Grosso do Sul. Arq. Biol. Tecnol., 31, 603-612.

Anjos, L. and Boçon, R. (1999), Bird communities in natural forest patches in southern Brazil. Wilson Bull., 111, 397-414.

Anjos, L. and Graf, V. (1993), Riqueza de aves da Fazenda Santa Rita, região dos Campos Gerais, Palmeira, Paraná, Brasil. Rev. Bras. Zool., 10, 673-693.

Anjos, L.; Schuchmann, K. L. and Berndt, R. (1997), Avifaunal composition, species richness, and status in the Tibagi River Basin, Parana State, Southern Brazil. Ornitol. Neotrop., 8, 145-173.

Bierregaard Jr., R. O. (1998), Conservation status of birds of prey in the south american tropics. J. Raptor Res., 32, 19-27.

Bildstein, K. L.; Schelsky, W. and Zalles J. (1998), Conservation status of tropical raptors. J. Raptor Res., 32, 3-18.

Brown, J. H. (1984), On the relationship between abundance and distribution of species. Am. Nat., 124, 255-279.

Brown, J. H. (1995), Macroecology. USA: The University of Chicago Press. 
Campos, J. B.; Romagnolo, M. B. and Souza, M. C. (2000), Structure, composition and spatial distribution of tree species in a remnant of the Semideciduous Seasonal Alluvial Forest of the Upper Paraná river floodplain. Braz. Arch. Biol. Technol., 43, 185-194.

Centrais Elétricas do Sul do Brasil. (1986), Ilha Grande. Eletrosul. v. 4. Relatório de Pesquisa. Florianópolis, Brasil.

Chapim III, F. S.; Zavaleta, E. S.; Eviner, V. T.; Naylor, R. L.; Vitousek, P. M.; Reynolds, H. L.; Hooper, D. U.; Lavorel, S.; Sala, O. E.; Hobbie, S. E.; Mack, M. C. and Díaz, S. (2000), Consequences of changing biodiversity. Nature, 405, 234-242.

Diniz-filho, J. A. F. and Bini, L. M. (1996), Assessing the relationship between multivariate community structure and environmental variables. Mar. Ecol. Prog. Ser., 143, 303-306.

Dobrowolski, K. A. (1994), Bird diversity in ecotonal habitats. Verh. Internat. Verein. Limnol., 25, 2491-2493.

Egler, S. G. (1991), Double-toothed kites following tamarins. Wilson Bull., 103, 510-512.

Ferrari, S. F. (1990), A foraging association between two kites species (Ictinea plumbea and Leptodon cayanensis) and buffy-headed marmosets (Callithrix flaviceps) in southeastern Brazil. Condor, 92, 781-783.

Fletcher Jr., R. J.; McKinney, S. T. and Bock, C. E. (1999), Effects of recreational trails on wintering diurnal raptors along riparian corridors in a Colorado grassland. J. Raptor Res., 33, 233-239.

Fortin, M. J. and Gurevitch, J. (1993), Mantel Tests: spatial structure in field experiments. In: Scheiner, S. M. and Gurevitch, J. (Eds.). Design and analysis of ecological experiments. Chapman e Hall Publishers. pp. 342-359.

Fowler, J.; Cohen, L. and Jarvis, P. (1998), Practical statistics for field biology. $2^{\text {nd }}$ ed. John Wiley \& Sons.

Fuller, M. (1996), Forest raptor population trends in North America. In: DeGraaf, R. M. and Miller, R. J. (Eds.). Conservation of faunal diversity in forested landscapes. Chapman \& Hall Publishers. pp. 167-208.

Fuller, M. and Mosher, J. A. (1987), Raptor survey techniques. In: Pendleton, B. A. G.; Millsap, B. A.; Kline, K. W. and Bird, D. M. (Eds.). Raptor management techniques manual. Washington, DC: National Wildlife Federation. pp. 37-66.

Fundação SOS Mata Atlântica and INPE. (1998), Atlas dos remanescentes florestais e ecossistemas associados no domínio da Mata Atlântica no período 1990-1995. São Paulo. Brasil.

Gamauf, A.; Preleuthner, M. and Winkler, H. (1998), Phillipine birds of prey: interrelations among habitat, morphology and behavior. Auk, 115, 713-726.

Gerhardt, R. P.; Harris, P. M. and Marroquín, M. A. V. (1993), Food habits of nesting Great Black Hawks in Tikal National Park, Guatemala. Biotropica, 25, 349-352.
Gilpin, M. E. and Soulé, M. E. (1986), Minimum viable populations: processes of species extinction. In: Soulé, M. E. (Ed.). Conservation Biology: The Science of Scarcity and Diversity. Massachussets: Sinauer Associates, Inc. Publishers. pp. 19-34.

Goosem, M. (1997), Internal fragmentation: The effects of roads, highways, and powerline clearings on movements and mortality of rainforest vertebrates. In: Laurence, W. F. and Bierregaard Jr., R. O. (Eds.). Tropical forest remnants: Ecology, management, and conservation of fragmented communities. Chicago: The University of Chicago Press. Chicago \& London. pp. 241-255.

Houston, D. C. (1985), Evolutionary ecology of afrotropical and neotropical vultures in forests. In: Buckley, P. A.; Foster, M. S.; Morton, E. S.; Ridgely, R. S. and Buckley, F. G. (Eds.). Neotropical ornithology. Washington, DC: The American Ornithologists Union. pp. 856-864.

Jongman, R. H. G.; ter Braack, C. J. F. and Van Tongeren, O. F. R. (1995), Data analysis in community and landscape ecology. New York, USA:Cambridge University Press.

Jordan, C. F. (1986), Local effects of tropical deforestation. In: Soulé, M. E. (Ed.). Conservation Biology: The Science of Scarcity and Diversity. Sinauer Associates, Inc. Publishers. Massachussets, pp. 410-426.

Krakauer, A. H. and Krakauer, T. H. (1999), Foraging of Yellow-headed Caracaras in the fur of a Threetoed Sloth. J. Raptor Res., 33, 270.

Krebs, C. J. (1998), Programs for ecological methodology. Version 5.1. Department of Zoology. Vancouver, Canada.

Krebs, C. J. (1999), Ecological methodology. $2^{\text {nd }}$ ed. Addison-Welsey Educational Publis.

Krügel, M. M. and Anjos, L. dos. (2000), Bird communities in forest remnants in the city of Maringá, Paraná State, southern Brazil. Ornitol. Neotrop., 11, 315-330.

Leisler, B. and Winkler, H. (1991), Ergegbnisse und Konzepte ökomorphologischer Untersuchungen an Vögeln. J. Ornit., 4, 373-425.

Lovejoy, T. E.; Bierregaard Jr., R. O.; Rylands, A. B.; Malcolm, J. R.; Quintela, C. E.; Harper, L. H.; Brown Jr., K. S.; Powell, A. H.; Powell, G. V. N.; Schubart, H. O. R. and Hays, M. B. (1986), Edge and other effects of isolation on Amazon forest fragments. In: Soulé, M. E. (Ed.). Conservation Biology: The Science of Scarcity and Diversity. Massachusetts: Sinauer Associates, Inc. Publishers. pp. 257-285.

Magalhães, C. A. (1990a), Comportamento alimentar de Busarellus nigricollis no pantanal de Mato Grosso, Brasil. Ararajuba, 1, 119-120.

Magalhães, C. A. (1990b), Hábitos alimentares e estratégia de forrageamento de Rostrhamus sociabilis no Pantanal de Mato Grosso, Brasil. Ararajuba, 1, 95-98. 
McCann, K. S. (2000), The diversity-stability debate. Nature, 405, 228-233.

McCune, B. and Mefford, M. J. (1999), PC-ORD for Windows: Multivariate analysis of ecological data. Version 4.01. MjM Software. Oregon, USA.

Meyer de Schauensee, R. (1982), A guide to the birds of South America. Philadelphia.

Newton, I. (1991), Population limitation in birds of prey: a comparative approach. In: Perrins, C. M.; Lebreton, J. D. and Hirons, G. J. M. (Eds.). Bird population studies: Relevance to conservation and management. New York: Oxford University Press. pp. 3-21.

Olrog, C. C. (1985), Status of wet forest raptors in northern Argentina. In: Newton, I. and Chancellor, R. D. (Eds.). Conservation studies on raptors. ICBP Technical Publication, n. 5. Cambridge, pp. 191-197.

Panasci, T. and Whitacre, D. (2000), Diet and foraging behavior of nesting Roadside Hawks in Petén, Guatemala. Wilson Bull., 112, 555-558.

Pinto, O. M. O. (1978), Novo catálogo de aves do Brasil: Aves não passeriformes e passeriformes não oscines, com exclusão da família Tyrannidae. $1^{\text {a }}$ Parte. Empr. Graf. Rev. Tribunais. São Paulo, Brasil.

Por, F. D. (1992), Sooretama: The Atlantic Rain Forest of Brazil. SPB Academic Publishing.

Preston, C. R. (1990), Distribution of raptor foraging in relation to prey biomass and habitat structure. Condor, 92, 107-112.

Price, T. (1991), Morphology and ecology of breeding warblers along an altitudinal gradient in Kashmir, India. J. Animal Ecol., 60, 643-664.

Ricklefs, R. E. (1989), Speciation and diversity: The integration of local and regional process. In: Otte, D. and Endler,J. A. (Eds.). Speciation and its consequences. Massachussets: Sinauer Associates, Inc. Publishers. pp. 599-621.

Robinson, S. K. (1994), Habitat selection and foraging ecology of raptors in Amazonian Peru. Biotropica, 26, 443-458.

Romagnolo, M. B. and Souza, M. C. (2000), Análise florística e estrutural de florestas ripárias do alto rio Paraná, Taquaruçu, MS. Acta Bot. Bras., 14, 163-174.

Sanchez-Zapata, J. A. and Calvo, J. F. (1999), Raptor distribution in relation to landscape composition in semi-arid Mediterranean habitats. J. Applied Ecol., 36, 254-262.

Scherer-Neto, P. and Straube, F. C. (1995), Aves do Paraná: história, lista anotada e bibliografia. Curitiba: Ed. dos Autores.

Seavy, N. E.; Schulze, M. D.; Whitacre, D. F. and Vasquez, M. A. (1997), Diet and hunting behavior of the Plumbeous Kite. Wilson Bull., 109, 526-532.

Sick, H. (1997), Ornitologia Brasileira. Rio de Janeiro: Nova Fronteira.

StatSoft, Inc. (1997), STATISTICA for Windows [Computer program manual]. Tulsa, OK.
Stevaux, J. C. (1994), Geomorfologia, sedimentologia e paleoclimatologia do Alto Curso do rio Paraná (Porto Rico, PR). Bol. Par. Geoc., 42, 97-112.

Stotz, D. F.; Fitzpatrick, J. W.; Parker III, T. A. and Moskovits, D. K. (1996), Neotropical birds: ecology and conservation. Chicago and London: The University of Chicago Press. University of Chicago.

Straube, F. C.; Bornschein, M. R. and Scherer-Neto, P. (1996), Coletânea da avifauna da região noroeste do estado do Paraná e áreas limítrofes (Brasil). Arq. Biol. Tecnol., 39, 193-214.

Thiollay, J. M. (1985a), Composition of falconiform communities along successional gradients from primary rainforest to secondary habitats. In: Newton, I. and Chancellor, R. D. (Eds.). Conservation studies on raptors. Cambridge: ICBP Technical Publication. n. 5. pp. 181-190.

Thiollay, J. M. (1985b), Species diversity and comparative ecology of rainforest falconiforms on three continents. In: Newton, I. and Chancellor, R. D. (Eds.). Conservation studies on raptors. Cambridge: ICBP Technical Publication. n. 5. pp. 167-179.

Thiollay, J. M. (1985c), The tropical rainforest raptors: state of knowledge, world situation and conservation strategy. In: Newton, I. and Chancellor, R. D. (Eds.). Conservation studies on raptors. Cambridge: ICBP Technical Publication. n. 5. pp. 223-225.

Thiollay, J. M. (1989), Area requirements for the conservation of rain forest raptors and game birds in French Guiana. Conserv. Biol., 3, 128-137.

Thiollay, J. M. (1991), Foraging, home range use and social behaviour of a group-living rainforest raptor, the Red-throated Caracara Daptrius americanus. Ibis, 133, 382-393.

Thiollay, J. M. (1994), A world review of tropical forest raptors: Current trends, research objectives and conservation strategy. In: Meyburg, B. U. and Chancellor, R. D. (Eds.). Raptor conservation today, WWGBP/The Pica Press. pp. 231-240.

Thiollay, J. M. (1996), Distributional patterns of raptors along altitudinal gradients in the northern Andes and effects of forest fragmentation. J. Trop. Ecol., 12, 535-560.

Thiollay, J. M. (1997), Disturbance, selective logging and bird diversity: a Neotropical forest study. Biodivers. Conserv., 6, 1155-1173.

Thiollay, J. M. (1999), Responses of an avian community to rain forest degradation. Biodivers. Conserv., 8, 513-534.

Thomaz, S. M.; Roberto, M. C. and Bini, L. M. (1997), Caracterização limnológica dos ambientes aquáticos e influência dos níveis fluviométricos. In: Vazzoler, A. E. A. M.; Agostinho, A. A. and Haan, N. S. (Eds.). A planície de inundação do alto rio Paraná: Aspectos físicos, biológicos e socio-econômicos. Maringá: EDUEM. pp. 73-102. 
Thorstrom, R. (1997), A description of nests and behavior of the Gray-headed kite. Wilson Bull., 109, 173-177.

Valentin, J. L. (1995), Agrupamento e ordenação: Tópicos em tratamentos de dados biológicos. In: PeresNeto, P. R.; Valentin, J. L. and Fernandez, F. A. S. (Eds.). Oecologia Brasiliensis. Rio de Janeiro: Universidade Federal do Rio de Janeiro. v. 2. pp. 2755.

Whitmore, T. C. (1997), Tropical forest disturbance, disappearance, and species loss. In: Laurence, W. F. and Bierregaard Jr., R. O. (Eds.). Tropical forest remnants: ecology, management, and conservation of fragmented communities. Chicago: The University of Chicago Press. Chicago \& London. pp. 3-12.

Zhang, S. and Wang, L. (2000), Following of brown capuchin monkeys by white hawks in French Guiana. Condor, 102, 198-201.

Received: October 15, 2003; Revised: October 20, 2004; Accepted: August 01, 2005. 